Lénart J. de Regt

United Bible Societies

1deregt@biblesocieties.org

\title{
Translating Biblical Poetry as Poetry
}

\section{Translation: more than a transfer of information}

What is translation? An initial definition could be: the transfer of a communication event between speaker and hearer, which already took place in a specific language and culture, for listeners (readers) in another language (which is part of another, different culture).

Of course communication involves more than conveying cognitive information. Part of communication is how this information is actually expressed and which genre or text-type is chosen. Whether the communication is in prose or poetry is only one basic genre classification. The choice of stylistic features, genre conventions and poetic features (which become part of the genre) determines what is being communicated to the hearer as much as the information content does. The choices that are made between the available stylistic, poetic and genre features shape the communication event between speaker and hearer, since they shape how the hearer is expected to receive and act upon the information.

How can such a communication event be transferred in translation? If only the information content is transferred without paying attention to the features just mentioned, the information content will not be carried and 
supported by those features. The hearer of the translation may receive the information content, but only in a distorted way, because the translation is not performing the other, non-informative functions of communication successfully. ${ }^{1}$ Instead, the translation should enable the hearer not just to appreciate the information content but at the same time learn, with the help of the stylistic and genre features, what kind of information it is, and whether and how it should be acted upon.

\section{Translating biblical poetry as a documentation of a communication event}

What does this mean for the translation of biblical poetry?

In the case of poetry in the Old Testament, there is a tendency to translate the information content as accurately as possible and at the same time to reproduce, in part, the poetic features of the Hebrew text. In practice, the poetic features that are being reproduced are the various types of parallelism (for example, synonymous, antithetic and progressive ${ }^{2}$ ). Another feature that can often be reproduced, after careful analysis, is the division of the text into lines (even if the poetic features of the language within these lines are not reproduced) and the segmentation of the text into stanzas, especially when the Hebrew text is an acrostic and thus divides the text into poetic lines, strophes, or stanzas. This is the case in Lamentations, some Psalms and a few other biblical passages. ${ }^{3}$

\footnotetext{
1 In line with Jakobson (1960) the functions of communication can be briefly described as follows: referential (reference to objects and phenomena); expressive (expression of emotions and other attitudes of the sender); appellative (appeal to the receiver to react and respond in a certain way); phatic (establishing and keeping the contact between sender and receiver), and poetic. Langeveld (1986: 114) describes poetic function as follows: "language can play its own part in the text" and what matters is "not just what is said but how [in which form] it is said". If these functions do not become part of the new communication event in translation, even the informationcontent itself will not be transferred successfully and suffer.

2 Or staircase parallelism, which applies when the second line includes a new element as well as some elements that are repeated from the first line. Examples are Psalm 121:5 (the second line adds 'al-yad yeminekha "at your right hand") and 7 (the second line adds 'et-nafshekha "your life").

3 These acrostics are Psalms 111 and 112 (in which each line/colon starts with an alphabetically successive Hebrew letter); Psalms 25, 34, 145 and Proverbs 31:10-31 (each bicolon starting with the next letter); Psalm 37 and Lamentations 1, 2, 4 (each strophe starting with the next letter); Lamentations 3 (in each successive stanza of three
} 
However, Hebrew acrostics are only very rarely reproduced by what are acrostic structures in their own right in the target language. ${ }^{4}$ And other Hebrew features, such as rhythm and sound patterns, are often considered impossible to reproduce in another language. This means that often Old Testament poetry is translated as poetry only to some extent. Although the communication event that was instigated by the biblical poem is transferred in translation, the poetic rhythm, meter and sound patterns of the source text are replaced in practice with prose in the target language. What the hearer of the translation receives, then, is a documentation of the communication event as it took place in the context of the source text, though only in part: the information content is indeed documented, and, optimistically, even some of the means of expression are documented (the parallelisms, line divisions and the segmentation), but the other means of expressing the information (the rhythms and sound patterns) are not. In this documentation of the source context's communication event, then, part of the communication event is missing. In the translation, the poetic text that was transferred is no longer poetry.

\section{Layout}

Translations often try to compensate for the above by presenting such texts in a poetic format and layout. While this may be a helpful way to show the parallelisms and segmentation, the result is that a poetic format is used for what has essentially become a prose text in the target language. Seeing the poetic format, the reader expects to engage with biblical poetry, but then finds out that it is actually prose, albeit in a specific layout.

As an aside, there is sometimes another problem with the layout of Psalms in existing translations. Especially when biblical poetry has actually

lines, each line starts with the same successive letter); Psalm 119 (in each successive stanza of eight lines, each line starts with the same successive letter). Incomplete acrostics are found in Psalm 9-10 and Nahum 1.

4 A rare example is found in the Traducción en lenguaje actual (2006), which is in Latin American Spanish. The translator of Lamentations, Alfredo Tepox, rendered the Hebrew acrostics very creatively into Spanish acrostics. In each of chapters 1, 2, and 4, the first letters of the successive strophes form the phrase " $P$ Pobrecita de ti, Jerusalén! [Jerusalem, you afflicted one!]", which is the opening phrase of the translation in 1:1. In chapter 3, the first letters of each successive stanza form the phrase "Yo soy el siervo sufriente [I am the suffering servant.]". (Esteban Voth kindly drew my attention to these Spanish acrostic translation examples.) 
been translated into prose, if no distinction is made between the format of the superscription of the Psalm and that of its main text, the reader may not realize that the superscription, even though it is part of the Hebrew text, is not part of the main text of the Psalm itself. We see this problem in many Bibles published electronically, especially within some biblical programs, such as Bible Works. An extreme example is found in Psalm 51, where several translations do not show that the main text of the Psalm only starts in the third verse, while the first two verses are nothing more than didascalia, an instruction intended for the choirmaster and, obliquely, for a potential audience. A quick solution would be to put these superscriptions in small capitals (as is done in Bible Works for the text of Biblia Sacra iuxta Vulgatam Versionem [2007]), in brackets (see ibidem the texts of The New King James Version and of the German Einheitsübersetzung der Heiligen Schrift [1980]) or in italics (as in La Sacra Bibbia della Conferenza Episcopale Italiana [2008], The New American Standard Bible [1977] or in the Polish Pismo Święte Starego i Nowego Testamentu. Najnowszy przekład z języków oryginalnych z komentarzem. Edycja Świętego Pawła [2008]). An example of a text outside Bible Works is NVILC, which puts Psalm superscriptions in small capitals. ${ }^{5}$

\section{Translating biblical poetry as a new communication event}

We now return to the subject of translating biblical poetry as such. Given that it is all but impossible to reproduce the rhythm, meter and sound patterns of the source text in the target language, a different translation method should also be considered. As we shall see, in some translations, a different method of translating biblical poetry has been applied.

As we said, a translation should enable the hearer not just to appreciate the information content but at the same time, with the help of stylistic and poetic means of expression and genre features, to learn what kind of information it is and whether and how it should be acted upon, and to benefit from how it is expressed.

This is not achieved by replacing non-reproducible poetic features of the source text with prose in the target language. Is there an alternative?

\footnotetext{
$5 \quad$ NVILC refers to Parola del Signore, La Bibbia: Nuova Versione Interconfessionale in Lingua Corrente (2014), Editrice Elledici, Torino / Società Biblica Britannica e Forestiera, Roma.
} 
If the information content is expressed with the help of stylistic, poetic and other genre features that are known in the context of the target language to match the kind of information content of the text to be translated, the hearer will not just receive the information content but also learn what kind of information it is and how it should be acted upon. In this approach, we would translate poetry in biblical Hebrew or Greek into a text of what is really considered the appropriate genre for such a text in the target culture. We would transfer biblical poetry into what the target culture would consider poetry (or another, specific genre considered fitting in the target culture), making use of stylistic, poetic and genre features that are considered appropriate specifically in the target language and for members of the target culture. Conventions in the target language have their own unique requirements and possibilities.

In this way, the translation is still the transfer of a communication event between speaker and hearer, which took place in a specific language and culture, for listeners (readers) in another language. It is, however, no longer just a documentation of that past communication event. Instead, the target- language-specific poetic and other features allow the translation to become a communication event directly between the text and the hearer of the target culture.

\section{Translating Psalms as new communication events in Dutch and Frisian}

We will now look into what difference this translation method makes and how it has been applied in a Dutch translation of Psalms 121 and 23, and a Frisian translation of Psalm 23.

\subsection{Psalm 121 in the Dutch translation of the Psalms by Gerhardt and van der Zeyde}

The Psalms translation of Ida Gerhardt and Marie van der Zeyde was published in 1972 and was included in the Roman Catholic Willibrord Translation in 1975. One of its main characteristics is that it strictly follows a specific Dutch poetic meter. They translated Psalm 121 as follows (I have numbered the lines, underlined the stressed syllables, and added an English rendering):

1 Ik hef op naar de bergen mijn ogen: I lift up to the mountains my eyes: 
2 vanwaar zal mij komen de hulp? from where shall to me come the help?

3 De hulp komt mij van de Heer, The help comes to me from the Lord,

4 die gemaakt heeft hemel en aarde. who has made heaven and earth.

5 Hij laat niet wank'len uw voet, He lets not waver your foot,

6 niet sluimeren zal uw behoeder. not slumber will your protector.

7 Zie, niet sluimert, niet slaapt

8 de behoeder van Israël.

See, not slumbers, not sleeps

the protector of Israel.

9 De Heer, Hij is uw behoeder,

10 de Heer is schaduw voor $\underline{u}$

11 aan $\underline{\underline{u w}}$ rechterzijde.

12 Bij dag zal de zon u niet steken,

13 noch de maan in de nacht.

The Lord, He is your protector,

the Lord is shadow for you

at the side on your right.

By day the sun shall not sting you,

nor the moon in the night.

14 De Heer zal u behoeden voor alle kwaad,

15 behoeden wil Hij uw ziel.

The Lord will protect you from all evil,

16 Hij behoedt uw uitgaan en ingaan

17 van thans tot in eeuwigheid.

Protect He wants to your soul.

He protects your going out and going in From now on to eternity.

The result is not just an accurate translation in terms of the information content of the Hebrew source text - it is a translation of Hebrew poetry into genuine Dutch poetry, combining many anapests ( - ) and a few iambs $(-)$. With the exception of line 14, the metrical pattern consists in having (no more than) three stressed syllables in one line, with one or two unstressed, short syllables in between the stressed ones. The second or third syllable in a line is the first stressed syllable. For grammatically long sentences, the last phrase is put on a new line (see lines $8,11,13,17$ ), so that lines do not become too long and there are no more than three stressed syllables in one line.

In order to maintain this metrical pattern throughout the poem, the poets had to make a few translation adaptations or transformations, adding a few monosyllabic words and removing one, and rearranging the Dutch word order for good reason in just a few cases. ${ }^{6}$ Interestingly, such adaptations were needed only to a very limited extent. I have put in the right column which type of transformation (according to Langeveld's terminology) has been applied in the translation and what the translation would

6 In his chapter on basic translation transformations, Langeveld distinguishes between transpositions, changes, additions and reductions; these different types of transformation are often combined (Langeveld 1986: 69-122). 
hypothetically have said if no adaptations had been made for the sake of the meter that we find in the actual translation on the left:

1 Ik hef op naar de bergen mijn ogen:

2 vanwaar zal mij komen de hulp?

3 De hulp komt mij van de $\underline{\text { Heer, }}$

4 die gemaakt heeft hemel en aarde.

5 Hij laat niet wank'len uw voet,

6 niet sluimeren zal uw behoeder.

7 Zie, niet sluimert, niet slaapt

8 de behoeder van Israël.

9 De Heer, Hij is uw behoeder,

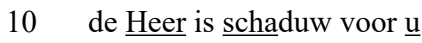

11 aan $\underline{\mathrm{uw}}$ rechterzijde.

12 Bij dag zal de zon u niet steken,

13 noch de maan in de nacht.

14 De Heer zal u behoeden voor alle kwaad,

15 behoeden wil Hij uw ziel.

16 Hij behoedt uw uitgaan en ingaan

17 van thans tot in eeuwigheid.
Instead of "Ik hef mijn ogen op naar de bergen" (transposition).

Article "de" inserted; instead of "mijn hulp" (change)

Instead of "mijn hulp" ( "my help")

(change).

Line 8 (subject) not after "Zie", but transposed to the end.

Addition of "Hij" ( "He"), an unstressed syllable.

Addition/change: "voor" ("for"), an unstressed syllable.
Addition of "wil" ("wants to").

Reduction: "Hij" ("He") instead of "de Heer" ( "the Lord”), for anapest.

These translational transformations help towards maintaining the Dutch meter as a means of expression. The target language-specific poetic features allow the translation to become a communication event more directly between the text and a hearer from the Dutch target culture. The hearer will not just receive the information content in prose but will be better able to respond to what has become again a poetic text. The communication event has become much less distant from the communication event in the source culture. 


\subsection{Psalm 23 in the Dutch translation of the Psalms by Gerhardt and van der Zeyde}

This applies to Gerhardt's and van der Zeyde's translation of Psalm 23 as well. (Again, I have numbered the lines, underlined the stressed syllables, and added an English rendering.)

1 De Heer is mijn herder,

2 mij zal niets ontbreken.

3 Hij wijst mij te liggen

4 in grazige weiden,

5 Hij voert mij naar wat'ren der rust.

6 Hij behoedt mijn ziel voor verdwalen,

7 Hij leidt mij in sporen van waarheid

8 getrouw aan zijn naam.

9 Moest ik gaan door het dal van de schaduw des doods,

10 kwaad zou ik niet vrezen.

11 Want naast mij gaat Gij,

12 uw stok en uw staf

13 zij doen mij getroost zijn.

14 Een tafel richt Gij mij aan

15 in het aangezicht van mijn belagers

16 en zalft met olie mijn hoofd.

17 Mijn beker vloeit over.

18 Zo zijn dan geluk en genade om mijn schreden

19 al de dagen mijns levens.

20 Verblijven mag $\underline{\mathrm{ik}}$ in het huis van de Heer

21 tot in lengte van dagen.
The Lord is my shepherd,

I shall nothing lack.

He shows me to lie

in green pastures,

He leads me to waters of rest.

He protects my soul from straying,

He leads me in paths of truth

faithful to his name.

Should I go through the valley of the shadow of death,

evil would I not fear.

Because by me Thou goest,

your rod and your staff

they make me be comforted.

A table Thou preparest me

in the face of my assailants

and anointest with oil my head.

My cup overflows.

So are then happiness and mercy around my steps

all the days of my life.

Dwell I may in the house of the

Lord

till length of days.

Again, the poets applied a few similar translation transformations (there are hardly any additions or reductions among them) for the sake of meter: 
1 De Heer is mijn herder,

2 mij zal niets ontbreken.

3 Hij wijst mij te liggen

Change: "He shows me to lie" instead of "He makes me lie".

4 in grazige weiden,

5 Hij voert mij naar wat'ren der rust.

6 Hij behoedt mijn ziel voor verdwalen, Change: "protects from straying" instead of "restores".

7 Hij leidt mij in sporen van waarheid

8 getrouw aan zijn naam.

Change: "faithful to" instead of "for the sake of".

9 Moest ik gaan door het dal van de schaduw des doods,

Reduction: "Even" (Hebrew gam) is not included.

10 kwaad zou ik niet vrezen.

11 Want naast mij gaat Gij,

Change: "by me Thou goest" instead of "with me Thou art"

12 uw stok en uw staf

13 zij doen mij getroost zijn.

Change: "make me be comforted" instead of "comfort me".

14 Een tafel richt Gij mij aan

15 in het aangezicht van mijn belagers

16 en zalft met olie mijn hoofd.

17 Mijn beker vloeit over.

18 Zo zijn dan geluk en genade om mijn Monosyllabic additions: "Zo ... dan" schreden

("So ... then").

Change: "are around my steps"

instead of "follow me".

19 al de dagen mijns levens.

20 Verblijven mag $\underline{\mathrm{ik}}$ in het huis van de Heer

21 tot in lengte van dagen.

This translation of Psalm 23 is a translation of Hebrew poetry into genuine Dutch poetry, again combining many anapests $\left({ }^{-}\right)$and a few iambs $(-)$. With the exception of lines 9,18 and 20, the metrical pattern 
consists in having not more than three stressed syllables in one line, with one or two unstressed, short syllables in between the stressed ones. The second or third syllable in a line is the first stressed syllable.

\subsection{Renderings of nefesh}

As their translation shows in both these Psalms, Gerhardt and van der Zeyde preferred to render the Hebrew nefesh as "ziel" ("soul"), rather than, say, "leven" ("life"), which would be more accurate in the context of the Old Testament from a semantic and exegetical point of view. Compare "vita" in NVILC and CEI and a form of "zycie" in PMB and PET ("life") in Psalm 121:7.7 In Psalm 23:3 PMB and PET have "duszę" ("soul") and CEI has "anima", but NVILC has "vigore" ("vigor").

\subsection{Psalm 23 in a Frisian translation by Fedde Schurer}

Frisian is mostly spoken in the province of Friesland in the north of the Netherlands. The poet Fedde Schurer put together a number of Psalm renderings in a poetry collection, "Psalmen yn 'e nacht" ("Psalms in the night") in 1945. What we see here is a poetic genre, a poem with Frisian poetic features, whose meter is close to the literature and cultural expectations of that target language. A Frisian translation along these lines is appropriate when the intention is to reduce the distance between the source text and culture on the one hand and hearers and readers from the target culture on the other, with the Frisian poetic features helping to bridge the cultural gap. Similarly to the Dutch translation by Gerhardt and van der Zeyde, this Frisian poem does not convey poetic features of the source text; these have not been transferred. Rather, the Frisian poetic features come in the place of Hebrew-based poetic features.

7 These abbreviations stand for the following versions: Parola del Signore, La Bibbia: Nuova Versione Interconfessionale in Lingua Corrente (2014), Editrice Elledici, Torino / Società Biblica Britannica e Forestiera, Roma. (NVILC); La Sacra Bibbia: Nuova Traduzione CEI [Conferenza Episcopale Italiana] (2015), Società Biblica Britannica e Forestiera, Roma. (CEI); Pismo Święte, Biblia Tysiąclecia, Starego i Nowego Testamentu (2003), Wydawnictwo Pallottinum, Poznań. <http://www.biblia.deon.pl>, visited 13 March 2021. (PMB); Pismo Święte, Starego Testamentu, Tom 3: Księgi Dydaktyczne Przekład Ekumeniczny z języków oryginalnych (2008), Towarzystwo Biblijne w Polsce, Warszawa. (PET). 
What was said about Gerhardt's and van der Zeyde's translation can be said about Schurer's Frisian poetry as well: the target language-specific poetic features allow the translation to become a communication event more directly between the text and a hearer of the Frisian target culture. The hearer will not just receive the information content in prose but will be better able to respond to what has become again a poetic text, with Frisian means of expression. For the hearer, the communication event has now become much less distant from the communication event in the source culture.

I have marked in bold what should be regarded as additions in comparison with the Hebrew source text. These adaptations and sometimes double translations are there for the sake of the poetic form. This is not to say, however, that we should reject this method of translation. In a new Frisian Bible translation it should be possible to turn this poem into an accurate translation by reducing these adaptations, still in keeping with the Frisian poetry.

Myn hoeder is myn God, myn help de Heare;

Neat bin ik brek, gjin ûnheil kin my deare.

Hy lit my rêste yn syn griene miede,

Hy wol my sêft oan freedge wetters liede.

Myn siel forkwikt Hy; om Syn namme en eare

Sil Hy ta 't spoar fan 't rjocht myn gongen keare.

Al moast ik ek yn 't dûnker deadsskaed stoarje,

Jo sille ek yn dy delling my biwarje.

Jins stôk en stêf sille îvich by my

bliuwe,

Myn siele treastgje en de need fordriuwe.
My shepherd is my God, my help the

Lord;

Nothing am I wanting, no harm can hurt me.

He lets me rest in his green meadow, He wants to lead me softly to peaceful waters.

My soul He refreshes; for His name and honour

will He to the path of justice turn my goings.

Even if I had to stare into the dark death's shadow,

You will also in that valley keep me Your rod and staff will eternally stay with me,

Comfort my soul and expel distress. 
Foar 't each fan dy't my haetsje djip yn 't herte,

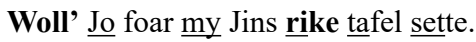

Mei kostlike oalje salvje Jo myn holle, Myn tsjelk fan heil ha Jo oerrinnend folle.

My folgje kleare goed en rju genede,

Myn libben leit oerljochte fan Jins frede.

Sa mei ik yn it hillich hûs des Heare

Yn langte fan myn dagen bliid forkeare.
For the eye of who hate me deep in the heart

You want to set for me Your rich table.

With precious oil You anoint my head, My chalice of salvation You have overflowingly filled.

Me follow clear goodness and ample mercy,

My life lies lit over by Your peace.

Thus may I in the holy house of the Lord

in length of my days happily dwell.

Stressed syllables are underlined. Additions in comparison with the Hebrew text are marked in bold. This poem consists of three stanzas, each of six lines. Each pair of lines has end rhyme. The metre is iambic $\left({ }_{-}\right)$ all the way through, with five iambs in each line, so that each line forms a pentameter.

While the main poetic feature in the Dutch poetry of Gerhardt and van der Zeyde is metre, Schurer combines a specific metre, rhyme and stanza structure in his Frisian poetry. This may explain why there are more translational adaptations in the Frisian Psalm rendering than in the Dutch ones. As we said, however, we should not reject this method of translation; in a new Frisian Bible translation it should be possible to turn this poem into an accurate translation by reducing these adaptations, still in keeping with Frisian poetry.

\section{A practical conclusion for translators}

This translation method is actually fitting for a translation that wants to reduce the distance between source text and source culture on the one hand and readers from the target culture on the other, instead of keeping that distance. This does not have to come at the expense of aspects of the source culture; the examples presented in this article illustrate that this approach 
can still lead to translations which render the information content of the source text accurately. It is precisely through the conventions and means of expression considered fitting in the target language that the text, along with its source culture and worldview, can be opened up, made accessible, and brought closer to the readers. ${ }^{8}$

Translators are encouraged to cast biblical poetry into poetic patterns of the target language, as they are accepted and expected in the target culture, rather than attempting but failing to reproduce the poetic features of the source text. In Bible translation, we need to be much more aware of what poetic and other genre features are available in the target culture as means of expression, and for what occasions they are used. Only then will we be able, for each type of biblical poetry, to choose a target culture genre and type of poetry that will fit the subject matter of the text in the context of that culture. This is especially important if the translation is to be fitting for oral delivery.

\section{References}

Gerhardt, I. M. G., and van der Zeyde, M. H. (1972), Psalmen uit het Hebreeuws vertaald, Katholieke Bijbelstichting, Boxtel.

Jakobson, R. (1960), "Linguistics and Poetics", in T. Sebeok, ed., Style in Language, Massachusetts Institute of Technology Press, Cambridge, 350-377.

Langeveld, A. (1986), Vertalen wat er staat, De Arbeiderspers, AmsterdamAntwerpen.

Nord, C. (2018), Translating as a Purposeful Activity: Functionalist Approaches Explained, Second Edition, Routledge, London-New York.

Schurer, F. (1974/1945), Psalmen yn 'e nacht. Republished in F. Schurer, Samle Fersen, FA 463, Bosch \& Keuning, Baarn-De Tille-Ljouwert-Fryslân, 260-282.

\footnotetext{
Abstract

After an introduction into translating biblical poetry as a new communication event in the target culture (and not as a documentation of a source culture event), an analysis is made of a Dutch poetic translation of Psalms 23

8 Another tangible, if somewhat radical example would be a translation of Psalms 126 and 137 into a poetic form which members of the target culture would associate with national songs of freedom or independence.
} 
and 121 and a Frisian poetic translation of Psalm 23. Of the poetic features and means of expression in these translations, Dutch and Frisian patterns ofmeter are the most important. When a poetic translation of biblical poetry follows genre conventions of the target language and culture (rather than attempting but failing to reproduce the poetic features of the source text), such a translation is able to generate a new, direct communication event that reduces the distance between the hearer/receiver of the target culture and the text of the source culture. Such a translation engages the hearer more effectively in responding to the text, because the poetic features of the target language facilitate the expressive, appellative and phatic functions of the communication. This should be an encouragement to translators to render different types of biblical poetry into different genres and poetic patterns of the target language that will actually fit the subject matter of the text into the context of the target culture.

Keywords: Bible translation, Biblical poetry, genre, meter, target language conventions 